\title{
Maturação do processamento auditivo em crianças com e sem dificuldades escolares***
}

\author{
Auditory processing maturation in children with and without learning \\ difficulties
}

Ivone Ferreira Neves* (ifneves@usp.br)

Eliane Schochat**

\begin{abstract}
*Fonoaudióloga. Doutora em Ciências pela Faculdade de Medicina da Universidade de São Paulo (FMUSP). Fonoaudióloga do Curso de Fonoaudiologia do Departamento de Fisioterapia, Fonoaudiologia e Terapia Ocupacional da FMUSP.

**Fonoaudióloga. Professora LivreDocente do Curso de Fonoaudiologia do Departamento de Fisioterapia, Fonoaudiologia e Terapia Ocupacional da FMUSP.

***Trabalho realizado no Curso de Fonoaudiologia do Departamento de Fisioterapia, Fonoaudiologia e Terapia Ocupacional da FMUSP.
\end{abstract}

Artigo de Pesquisa

Artigo Submetido a Avaliação por Pares

Conflito de Interesse: não

Recebido em 3.11.2004

Revisado em 18.01.2005; 17.05.2005; 20.07.2005; 31.10.2005.

Aceito para Publicação em 31.10.2005.

\section{Abstract}

Background: auditory processing maturation in school children with and without learning difficulties. Aim: to verify response improvement with the increase in age of the auditory processing skills in school children with ages ranging from eight to ten years, with and without learning difficulties and to perform a comparative study. Method: eighty-nine children without learning complaints (Group I) and 60 children with learning difficulties (Group II) were assessed. The used auditory processing tests were: Pediatric Speech Intelligibility (PSI), Speech in Noise, Dichotic Non-Verbal (DNV) and Staggered Spondaic Word (SSW). Results: a better performance was observed for Group I between the ages of eight and ten in all of the used tests. However, the observed differences were statistically significant only for PSI and SSW. For Group II, a better performance was also observed with the increase in age, with statistically significant differences for all of the used tests. Comparing the results between Groups I and II, a better performance was verified for children with no learning difficulties, in the three age groups, in PSI, DNV and SSW. Conclusion: a statistically significant improvement was verified in the responses of the auditory processing with the increase in age, for the ages between eight and ten years, in children with and without learning difficulties. In the comparative study, it was verified that children with learning difficulties presented a lower performance in all of the used tests in the three age groups. This suggests, for this group, a delay in the maturation of the auditory processing skills. Key Words: Hearing; Hearing Disorders; Auditory Perception; Learning.

\section{Resumo}

Tema: maturação do processamento auditivo em escolares com e sem dificuldades escolares. Objetivo: verificar a melhora de resposta com o aumento da idade em habilidades do Processamento Auditivo em crianças com idades de oito, nove e dez anos, com e sem dificuldades escolares, e realizar estudo comparativo. Método: foram avaliadas 89 crianças sem queixas de dificuldades escolares (Grupo I) e 60 com queixas de dificuldades escolares (Grupo II). Os testes do processamento auditivo aplicados foram o Pediatric Speech Inteligibility (PSI), o Fala com Ruído, o Dicótico Não Verbal (DNV) e o Sttagered Spondaic Word (SSW). Resultados: no Grupo I, foi verificado melhor desempenho na resposta entre as idades de oito e dez anos para todos os testes, mas com diferenças estatisticamente significantes apenas para os testes PSI e SSW. Para o Grupo II, também foi verificado melhor desempenho na resposta com o aumento da idade, com diferenças estatisticamente significantes, para todos os testes. No estudo comparativo entre o Grupo I e o Grupo II, para o desempenho em cada teste e para cada faixa etária, verificou-se melhor desempenho no grupo de crianças sem dificuldades escolares, nas três faixas etárias, nos testes PSI, DNV e SSW. Conclusão: neste estudo, verificou-se a melhora de resposta com o aumento da idade, estatisticamente significante, no desempenho de habilidades do processamento auditivo para as faixas etárias entre oito e dez anos, tanto em crianças sem dificuldades escolares como nas com queixa de dificuldades escolares. No estudo comparativo, verificou-se que as crianças do grupo com dificuldades escolares apresentaram pior desempenho em todos testes aplicados e para as três faixas etárias, sugerindo atraso na maturação das habilidades do processamento auditivo neste grupo.

Palavras-Chave: Audição; Transtorno da Audição; Percepção Auditiva; Aprendizagem. \footnotetext{
NEVES, I. F.; SCHOCHAT, E. Auditory processing maturation in children with and without learning difficulties (original title: Maturação do processamento
auditivo em crianças com e sem dificuldades escolares (original title: Auditory processing maturation in children with and without learning difficulties. Pró-Fono Revista de Atualização Científica, Barueri (SP), v. 17, n. 3, p. 311-320, set-dez. 2005.
} 


\section{Introduction}

The auditory processing skills evaluation has provided a great contribution for the identification and for the intervention of children with learning difficulties.

According to the consensus promoted by the American Speech-Language Association (ASHA), the auditory processing was defined as "mechanisms and processes of the auditory nervous system" (ASHA, 1995), that enable the speech decoding and understanding, specially in unfavorable situations, such as in the presence of background noise or competitive speech (Jerger and Musiek, 2000).

The first auditory processing tests emerged with the necessity to evaluate the central auditory pathway for the identification and the localization of cerebral lesions. Bocca et al. (1954) were one of the first researchers to use speech stimuli in a dichotic presentation, verifying worse responses in the ear contra-lateral to the hemispherical lesion.

Nowadays, the association between learning difficulties and auditory skills development disorders has been one of the main focus of studies performed with auditory processing tests (Bamiou et al., 2001; Chermak and Musiek, 2002; Heiervang et al., 2002; Moncrieff and Musiek, 2002; Phillips, 2002; Purdy et al., 2002; Wertz et al., 2002; King, 2003).

Several auditory processing tests were elaborated in Brazil, as reported by Pereira and Schochat (1997) and there are several studies associating the Auditory Processing disorder with learning difficulties (Câmara, 1998; Almeida, 2000; Fellipe, 2000; Lemos, 2000; Garcia, 2001; Fellipe and Colafêmina, 2002; Frota, 2003).

The auditory processing disorders that present a manifestation diversity may be identified by electrophysiological tests, which verify the auditory pathway integrity, and by behavioral tests which evaluate the auditory function, that is, the auditory skills. The precision on the audiological diagnosis and on the therapeutic planning will depend on the adequate interpretation of the auditory processes evaluation (Bamiou et al. 2001; Chermak and Musiek, 2002).

Among the several aspects involved in the auditory processing diagnostic evaluation, Musiek and Gollegly (1988) stressed the auditory maturation. The authors affirmed that the auditory tests are dependent on the neural function and must be interpreted within a "neuromaturational" context.
Schochat (2001) stressed that the main goals of the central auditory evaluation are to verify the integrity and the neuro-maturation status of the auditory pathway.

The maturation of the auditory pathway has been documented in several studies with the electrophysiological tests (Ponton et al., 2000; Kraus, 2001; Schochat, 2001; Purdy et al., 2002), where it was verified better responses from birth until the age of 12 years, when the responses patterns became similar to the adults' ones.

Regarding the auditory processing behavioral tests, some studies reported an evident quantitative improvement in the responses with the increase of age, specially between the ages of eight and ten years (Musiek and Gollegly, 1988; Chermak and Musiek, 1992; Câmara, 1988; Almeida, 2000; Schochat et al., 2000; Phillips, 2002; Costa et al., 2004). However, only a few studies had as a central proposition to verify the maturation effect on the behavioral responses.

In a study performed with children presenting learning disorders, Musiek and Gollegly (1988) found a little response improvement with the increase of age, specially in the dichotic tests. The authors associated this data to the possible late maturation of the corpus callosum - the involved area in dichotic tests. They concluded that the maturation aspects are specially interesting in cases of learning disorders, once they occur in children who frequently present a delay in the development of auditory skills.

Ponton et al. (2000) affirmed that the verification of the auditory responses maturation provides data for the correct planning of stimulations according to the degree of delay found.

Schochat (2001) studied the effect of maturation on the performance of auditory processing tests. The author verified the maturation for the temporal ordering skill in normally hearing children, aging between seven and 16 years, when the responses pattern became similar to the adults' one. In this study, the author concluded that the behavioral evaluation may reflect the neural system immaturity, and this is an essential factor for the diagnosis and management of the rehabilitation process.

The correct interpretation of the behavioral tests in the auditory processing evaluation will, therefore, request the determination of the normality criteria regarding the maturation processes. 
Therefore, the aim of this study was to verify the maturation of auditory processing skills of children with and without learning difficulties, aging eight, nine and ten years old.

For this study, the significant improvement in the auditory processing as the age increased, was associated to the auditory maturation process of these ages. Furthermore, it is believed that the worse performance in auditory processing tasks of children with learning difficulties may be a manifestation of maturation delay.

In this study, four auditory abilities were verified in relation to three age groups (eight, nine and ten years old). It is believed that from seven years old, children are ready to respond to auditory processing behavioral tests (Pereira and Schochat, 1997), and that there might be an improvement in the performance until the age of ten years old (Chermak and Musiek, 1992; Câmara, 1998; Almeida, 2000; Schochat et al., 2000).

\section{Method}

The children's parents or legal guardians agreed to voluntarily participate of the study after signing the informed consent term (protocol no. 731/01). The sample size was appropriate for the purpose of this study.

\section{Subjects}

149 school children, 82 female and 67 male from public Primary Schools of São Paulo city, aging eight, nine and ten years old took part in this study.

The inclusion criteria for the participants were: absence of evident neurological, psychiatric and hearing disorders; they should attend a public Primary School and be from eight to ten years old.

According to the school teacher's interview, the participants were distributed in two study groups, with and without learning difficulties. Group I was composed by 89 participants without learning difficulties: 39 aging eight years old, 29 aging nine and 26 aging 10 years old. Group II was composed by 60 participants with learning difficulties: 20 aging eight, 20 aging nine and 20 aging 10 years old.

\section{Method}

The equipments used for the audiological evaluation were: a Heine otoscope, a soundproof booth, a Grason-Stadler GSI-61 audiometer (ANSI, 1989); earphones TDH 50; lists of disyllable and trissyllables words; a Grason-Stadler GSI-33 middle ear analyzer (ANSI, 1987).

For the auditory processing behavioral evaluation, a Panassonic CD player connected to the GSI-61 audiometer; CDs volumes I and II with the tests recordings; and a picture poster with the responses for the PSI and NVD tests, edited by Pereira and Schochat (1997), were used.

All participants underwent the basic audiological evaluation (pure tone and speech audiometry and immitance measures) and the auditory processing evaluation in the SpeechLanguage Laboratory on Auditory Processing of the Speech-Language Department - Medicine School of the University of São Paulo (FMUSP).

The tests administration followed the recommendations established in the "Auditory Processing Evaluation Manual" published by Pereira and Schochat (1997).

From this Manual, two monotic tests were applied - PSI for the selective attention skill with visual support, and Speech in Noise for the auditory closure skill. Two dichotic tests were also applied: the Non-Verbal Dichotic test (NVD) with Focused Attention for the focused attention skill, and the SSW for the analysis-synthesis skill.

The PSI test involved the identification of sentences with competitive message, with a visual support for the correct response. The participant was instructed to hear a story and, simultaneously, he would be asked to point a figure presented in the poster in front of him.

For the Speech in Noise test, the participant was instructed to hear a series of monosyllabic words together with a noise, and he should repeat the words he heard.

For the NVD test, that involves the identification of two different non verbal sounds presented in each ear simultaneously, the participant was asked firstly to point the picture corresponding to the sounds presented only in the right ear, and then, to the sounds presented in the left ear.

For the SSW test, that involves the identification of four different disyllables presented simultaneously in both ears, the participant was asked to repeat the four words.

According to the purposes of this research, the statistical analysis aimed at verifying the significant differences in the auditory skills performance according to the age. Therefore, the analysis of variance parametric test ANOVA was used. The significance level used was 0,05 (5\%); for values higher than 0,05 the null hypothesis was 
considered true (no difference between the groups) and, for the contrary, the alternative hypothesis was considered true (significant statistical difference between the groups).

\section{Results}

Table 1 presents the results of Group I, composed by children without learning difficulties.

In this Group, the older the children, the better the responses in all tests. However, significant statistical differences were found between the averages of correct responses in the PSI and SSW tests.

Thus, in order to determine the age group responsible for the significant difference, the comparisons were made two-by-two for these two tests (Table 2).

In Group I, significant statistical differences were found in the PSI test comparing the correct responses averages between the age groups of eight and nine years old and between the age groups of eight and tem years old. In the SSW test, a significant statistical difference was found between the age groups of eight and nine years old.

Graph I shows the averages of correct responses of Group I, for each age group in the four tests.

Table 3 presents the results of Group II, composed by children with learning difficulties.

In this Group, significant statistical differences were found between the averages of correct responses in all tests according to the age increase. Therefore, it was also necessary to analyze the age groups two-by-two in order to verify which one was responsible for the difference.
In Group II, there was significant difference in the PSI test between the age groups of eight and nine years old, and of eight and ten. In the Speech in Noise test, there were significant differences between the ages eight and ten years old, and nine and ten years old. In the NVD test, a significant difference was found between the ages eight and nine years old. In the SSW test, there were significant differences between the age groups of eight and nine years old, and eight and ten years old.

Graph 2 illustrates the averages of correct responses of Group II, in the four tests according to the age group

In the majority of the tests, it was verified a worse performance in the group with learning complaints (Group II) in relation to the group of participants without learning complaints (Group I). However, for each test the significant differences occurred in distinct age groups.

In the PSI test, a significant difference was found between the average of correct responses of Group I and Group II at the age of nine years.

In the Speech in Noise test, a significant difference was found between the average of correct responses of Groups I and II, at the age of ten years.

In the NVD test, the significant differences were observed in the age groups of eight and ten years old.

And, in the SSW test, there were significant differences between the averages of correct responses of Group I and Group II in all age groups. 
TABLE 1. Distribution of averages, standard desviations and significance level obtained in each test, according to the age in group I

\begin{tabular}{c|c|cccc}
\multicolumn{2}{c|}{ Grupo I } & Média & Desvio Padrão & Tamanho & P-Valor \\
\hline \multirow{3}{*}{ PSI } & 8 Anos & $74,4 \%$ & $12,7 \%$ & 68 & \\
& 9 Anos & $83,3 \%$ & $11,0 \%$ & 58 & $<0,001^{*}$ \\
& 10 Anos & $83,1 \%$ & $12,5 \%$ & 52 & \\
\hline \multirow{3}{*}{ Fala com Ruído } & 8 Anos & $67,0 \%$ & $8,6 \%$ & 68 & \\
& 9 Anos & $68,3 \%$ & $8,7 \%$ & 58 & 0,223 \\
& 10 Anos & $69,8 \%$ & $8,7 \%$ & 52 & \\
\multirow{5}{*}{ DNV } & 8 Anos & $90,2 \%$ & $11,9 \%$ & 68 & \\
& 9 Anos & $88,8 \%$ & $18,4 \%$ & 58 & 0,094 \\
& 10 Anos & $94,4 \%$ & $10,0 \%$ & 52 & \\
& 8 Anos & $76,1 \%$ & $13,1 \%$ & 68 & \\
& 9 Anos & $82,3 \%$ & $11,3 \%$ & 58 & $0,023^{*}$ \\
& 10 Anos & $80,1 \%$ & $13,3 \%$ & 52 &
\end{tabular}

$*$ diferenças estatisticamente significantes.

Legenda: PSI = Pediatric Speech Inteligibility; DNV = Dicótico Não Verbal; SSW = Sttagered Spondaic Word .

TABLE 2. Results of the p-values found in the comparison between the PSI and SSW tests for each age group in group I

\begin{tabular}{|c|c|c|c|}
\hline & po I & $\begin{array}{c}\text { P-Valores } \\
8 \text { Anos }\end{array}$ & 9 Anos \\
\hline \multirow{2}{*}{ PSI } & 9 Anos & $<0,001^{*}$ & \\
\hline & 10 Anos & $<0,001 *$ & 0,929 \\
\hline \multirow{2}{*}{ SSW } & 9 Anos & $0,006^{*}$ & \\
\hline & 10 Anos & 0,107 & 0,354 \\
\hline
\end{tabular}

* = diferenças estatisticamente significantes.

GRAPH 1. Averages of correct responses of the participants without learning difficulties (Group I) according to the age, in each auditory processing test.

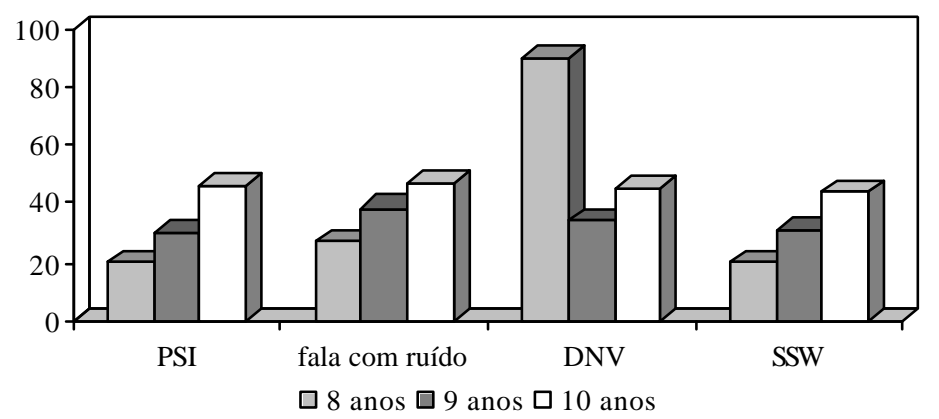

Legenda: PSI = Pediatric Speech Inteligibility; DNV = Dicótico Não Verbal; SSW = Sttagered Spondaic Word . 
TABLE 3. Distribution of averages, standard desviations and significance level obtained in eache test, according to the age in group II.

\begin{tabular}{cccccc}
\multicolumn{2}{c}{ Grupo II } & Média & Desvio Padrão & Tamanho & P-Valor \\
& 8 Anos & $70,8 \%$ & $13,3 \%$ & 40 & \\
PSI & 9 Anos & $78,5 \%$ & $12,7 \%$ & 40 & $0,007^{*}$ \\
& 10 Anos & $80,0 \%$ & $15,5 \%$ & 40 & \\
Fala com & 8 Anos & $68,4 \%$ & $9,8 \%$ & 40 & \\
Ruído & 9 Anos & $67,2 \%$ & $9,5 \%$ & 40 & $0,007^{*}$ \\
& 10 Anos & $73,7 \%$ & $9,7 \%$ & 40 & \\
& 8 Anos & $76,3 \%$ & $20,6 \%$ & 40 & \\
DNV & 9 Anos & $86,7 \%$ & $17,6 \%$ & 40 & $0,049^{*}$ \\
& 10 Anos & $82,7 \%$ & $18,5 \%$ & 40 & \\
\hline \multirow{2}{*}{ SSW } & 8 Anos & $62,4 \%$ & $16,0 \%$ & 40 & \\
& 9 Anos & $71,6 \%$ & $13,3 \%$ & 40 & $0,004 *$ \\
& 10 Anos & $73,3 \%$ & $16,3 \%$ & 40 &
\end{tabular}

$*$ diferenças estatisticamente significantes.

Legenda: PSI = Pediatric Speech Inteligibility; DNV = Dicótico Não Verbal; SSW = Sttagered Spondaic Word .

TABLE 4. Results of the p-values found in the comparison between the psi, speech in noise, nvd and ssw tests for each age group in group II.

\begin{tabular}{|c|c|c|c|}
\hline \multicolumn{2}{|c|}{ Grupo II } & P-Valores & 9 Anos \\
\hline \multirow{2}{*}{ PSI } & 9 anos & $0,009^{*}$ & \\
\hline & 10 anos & $0,005^{*}$ & 0,638 \\
\hline \multirow{2}{*}{ Fala com Ruído } & 9 anos & 0,595 & \\
\hline & 10 anos & $0,016^{*}$ & $0,003 *$ \\
\hline \multirow{2}{*}{ DNV } & 9 anos & $0,017^{*}$ & \\
\hline & 10 anos & 0,145 & 0,331 \\
\hline \multirow{2}{*}{ SSW } & 9 anos & $0,007 *$ & \\
\hline & 10 anos & $0,003 *$ & 0,601 \\
\hline
\end{tabular}

$*=$ diferenças estatisticamente significantes.

GRAPH 2. Averages of correct responses of the participants with learning difficulties (Group II) according to the age, in each auditory processing test.

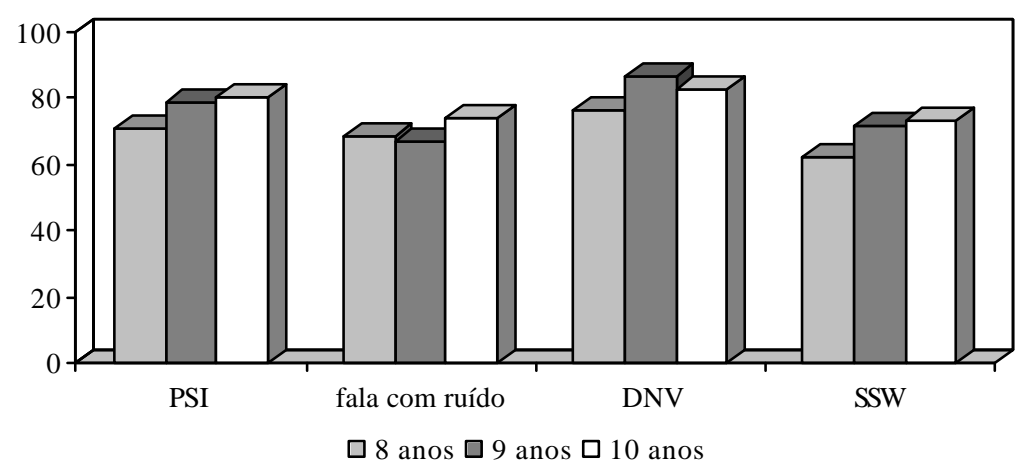

Legenda: PSI = Pediatric Speech Inteligibility; DNV = Dicótico Não Verbal; SSW = Sttagered Spondaic Word . 
TABLE 5. Comparison between the averages and standard deviations of correct responses found in group I and group II according to the age group. in the PSI test.

\begin{tabular}{ccccc|cc} 
& \multicolumn{2}{c}{8 Anos } & \multicolumn{2}{c|}{9 Anos } & \multicolumn{2}{c}{10 Anos } \\
PSI & Grupo I & Grupo II & Grupo I & Grupo II & Grupo I & Grupo II \\
\hline média & $74,4 \%$ & $70,8 \%$ & $83,3 \%$ & $78,5 \%$ & $83,1 \%$ & $80,0 \%$ \\
desvio & $12,7 \%$ & $13,3 \%$ & $11,0 \%$ & $12,7 \%$ & $12,5 \%$ & $15,5 \%$ \\
padrão & 68 & 40 & 58 & 40 & 52 & 40 \\
tamanho & 68 & \multicolumn{2}{c}{$0,050^{*}$} & \multicolumn{2}{c}{0,294} \\
p-valor & 0,159 & \multicolumn{3}{c}{} \\
\hline
\end{tabular}

* = diferenças estatisticamente significantes.

Legenda: PSI = Pediatric Speech Inteligibility.

TABLE 6. Comparison between the averages and medians of correct responses of groups i and ii according to the age group, in the speech in noise test.

\begin{tabular}{ccccccc} 
Fala com & \multicolumn{2}{c}{8 Anos } & \multicolumn{2}{c}{9 Anos } & \multicolumn{2}{c}{10 Anos } \\
\cline { 2 - 7 } Ruído & Grupo I & Grupo II & Grupo I & Grupo II & Grupo I & Grupo II \\
média & $67,0 \%$ & $68,4 \%$ & $68,3 \%$ & $67,2 \%$ & $69,8 \%$ & $73,7 \%$ \\
desvio & $8,6 \%$ & $9,8 \%$ & $8,7 \%$ & $9,5 \%$ & $8,7 \%$ & $9,7 \%$ \\
padrão & & 40 & 58 & 40 & 52 & 40 \\
tamanho & 68 & 40 & \multicolumn{2}{c}{0,539} & \multicolumn{2}{c}{$0,044 *$} \\
p-valor & \multicolumn{2}{c}{0,456} & & & & \\
\hline
\end{tabular}

*= diferenças estatisticamente significantes.

TABLE 7. Comparison between the averages and medians of correct responses of groups $i$ and ii according to the age group, in the NVD test.

\begin{tabular}{ccccccc} 
& \multicolumn{2}{c}{8 Anos } & \multicolumn{2}{c}{9 Anos } & \multicolumn{2}{c}{10 Anos } \\
\cline { 2 - 7 } DNV & Grupo I & Grupo II & Grupo I & Grupo II & Grupo I & Grupo II \\
média & $90,2 \%$ & $76,3 \%$ & $88,8 \%$ & $86,7 \%$ & $94,4 \%$ & $82,7 \%$ \\
desvio & $11,9 \%$ & $20,6 \%$ & $18,4 \%$ & $17,6 \%$ & $10,0 \%$ & $18,5 \%$ \\
padrão & 68 & 40 & 58 & 40 & 52 & 40 \\
tamanho & 68 & \multicolumn{2}{c}{0,568} & $<0,001^{*}$ \\
p-valor & $<0,001^{*}$ & \multicolumn{3}{c}{} \\
\hline
\end{tabular}

* diferenças estatisticamente significantes.

Legenda: DNV = Dicótico Não Verbal.

TABLE 8. Comparison between the averages and medians of correct responses of groups i and ii according to the age group, in the SSW test.

\begin{tabular}{cc|ccccc|}
\multirow{2}{*}{ SSW } & \multicolumn{2}{c}{8 Anos } & \multicolumn{2}{c}{9 Anos } & \multicolumn{2}{c}{10 Anos } \\
\cline { 2 - 7 } & Grupo I & Grupo II & Grupo I & Grupo II & Grupo I & Grupo II \\
média & $76,1 \%$ & $62,4 \%$ & $82,3 \%$ & $71,6 \%$ & $80,1 \%$ & $73,3 \%$ \\
desvio & $13,1 \%$ & $16,0 \%$ & $11,3 \%$ & $13,3 \%$ & $13,3 \%$ & $16,3 \%$ \\
padrão & 68 & 40 & 58 & 40 & 52 & 40 \\
tamanho & 68 & $<0,001^{*}$ & $0,031^{*}$ \\
p-valor & $<0,001^{*}$ & \multicolumn{3}{c}{} \\
\hline
\end{tabular}

* = diferenças estatisticamente significantes.

Legenda: SSW = Sttagered Spondaic Word. 


\section{Discussion}

The neural maturation is one of the processes that occur during the individual's development for the complete structuring and functioning of the nervous system (Kolb and Whishaw, 2002). In this study, a correlation between the behavior and the neural development was observed, that is, between the development of auditory skills and the neural maturation (Chermak and Musiek, 1992; Ponton et al., 2000; Kraus, 2001; Moore, 2002; Phillips, 2002).

Concerning Group I, with participants without complaints of learning difficulties, it was verified that the older the children, the better the performance in the four auditory processing tests (PSI, Speech in Noise, NVD and SSW), although the differences were statistically significant only for the PSI and SSW tests (Tables 1 and 2; Graph 1). Thus, it was observed an evident difference of performance between the ages of eight and ten years old in all tests; the age of nine years old could be considered a transition age, sometimes with a performance similar to the age of eight years, sometimes similar to the age of ten years old.

Although no national studies with an age group analysis of the auditory processing tests had been found, the results observed here were compared to those involving school age children.

In the PSI test, the results of this study agreed with the ones found by Garcia (2001), who encountered an average of $89 \%$ for children aging over nine years old. These data confirmed an improvement of the performance in this test, between the ages of eight and nine years old.

In the Speech in Noise test, the results observed in this study agreed with the ones found by Frota (2003), if we consider the age groups involved in the studies; the author evaluated children between nine and 12 years of age and obtained averages of correct responses higher than the ones found in this study $(81,0 \%)$. The improvement of the performance between the ages of eight and ten years old was also verified in this test.

The higher averages of correct responses were observed in the NVD test and this result agreed with Lemos (2000) and Frota (2003) who also reported elevated averages of correct responses (95\% and 96\%). These data may indicate that for the studied age groups, the maturation of the auditory skill involved in the NVD test occurred before eight years of age.

In the SSW test, the averages of correct responses were lower than those reported in the literature. Câmara (1998) found an average of 92\% of correct responses for the age group between nine and ten years old, and Frota (2003) found an average of $90,1 \%$ of correct responses for children aging from nine to 12 years old. Perhaps, the difference in the socio-cultural level of the participants of the three studies could justify these differences. Furthermore, as already reported, the authors didn't aim at analyzing by age groups, making difficult the comparison of the results. Nevertheless, in this study, involving a younger age group (eight years old), lower percentages of correct responses were found when compared to the studies of Câmara (1998) and Frota (2003).

With these results, it was possible to affirm that neural maturation aspects interfered significantly on the performances of auditory processing behavioral tests in the ages of eight, nine and ten years old.

Concerning the Group II, with participants with learning difficulties, it was observed that, the older the children the better their responses, with significant statistical differences in all tests (Tables 3 and 4; Graph 2). This result indicated that the maturation aspect also interfered on the tests' performance, however less gradually and more discrepantly between one age group and the other.

The comparative study between Groups I and II was performed for each test, according to the ages of eight, nine and ten years old.

Tables 5, 6, 7 and 8 show that the averages of correct responses of Group II were lower than the ones found in Group I in three of the applied tests (PSI, NVD and SSW).

This result agreed with the literature that repots an association between the auditory processing disorder and the learning difficulties, indicating the necessity of the evaluation of auditory abilities in children with learning difficulties (Câmara, 1998; Almeida, 2000; Lemos, 2000; Bamiou et al. 2001; Garcia, 2001; Moncrieff and Musiek, 2002; Frota, 2003).

Chart 1 presents the description of the averages of correct responses for each test according to the age group, in Groups I and II. It can be verified that the older the children, the better the responses in both groups and, in Group II, with participants with learning difficulties, the responses were worse than in Group I, indicating a maturational delay of the auditory abilities of focused attention, figureground and analysis-synthesis. 
Concerning the auditory closure ability, verified by the Speech in Noise test, it was observed a similar performance in Group I and Group II for the ages of eight and nine years old. At ten years of age, it was observed a better performance of Group II, indicating that this test is not very adequate to differ children with and without learning difficulties.
Chart 1 also shows that, besides the improvement of the responses with the increase of age, a better performance according to the involved ability was observed. Therefore, the attention skill for non-verbal sounds (NVD test) presented better performance, followed by the figure-ground skill with visual support (PSI-MCI test), the analysissynthesis for verbal stimuli and the auditory closure for verbal stimuli (Speech in Noise test).

CHART 1. Results of the auditory processing abilities performances according to the ages of eight, nine and tem years old in children without (Group I) and with learning difficulties (Group II).

\begin{tabular}{c|c|cccc|cc}
\multirow{2}{*}{ Teste } & Habilidade & \multicolumn{2}{c}{8 Anos } & \multicolumn{2}{c}{9 Anos } & \multicolumn{2}{c}{10 Anos } \\
& & GI & GII & GI & GII & GI & GII \\
\hline DNV & atenção direcionada & $90,2 \%$ & $76,3 \%$ & $88,8 \%$ & $86,7 \%$ & $94,4 \%$ & $82,7 \%$ \\
PSI-MCI & figura-fundo & $74,4 \%$ & $70,8 \%$ & $83,3 \%$ & $78,5 \%$ & $83,1 \%$ & $80,0 \%$ \\
SSW & analise-síntese & $76,1 \%$ & $62,4 \%$ & $82,3 \%$ & $71,6 \%$ & $80,1 \%$ & $73,3 \%$ \\
fala com ruído & fechamento & $67,0 \%$ & $68,4 \%$ & $68,3 \%$ & $67,2 \%$ & $69,8 \%$ & $73,7 \%$ \\
\hline
\end{tabular}

Legenda: PSI = Pediatric Speech Inteligibility; DNV = Dicótico Não Verbal; SSW = Sttagered Spondaic Word .

\section{Conclusion}

From the analysis of the results obtained in this study, it was verified that in the group of children without learning difficulties complaints, the older the children, the better the responses for all tests applied, mainly between the ages of eight and ten years old, and this difference was statistically significant in the PSI and SSW tests.

In the group of children with learning difficulties, it was also verified that the older the children, the better the responses for all tests, however not gradually and more discrepantly between the age groups; these differences were statistically significant in all tests. Therefore, it was observed that children with learning difficulties may present maturational delay of important and necessary auditory abilities for the reading and writing learning process. This study contributed to emphasize the maturation aspect in the obtaining of a precise audiological diagnosis. Moreover, it stresses the convenience of the auditory stimulation in these age groups, not only as a therapeutic measure, but also for the appropriate development of auditory abilities.

\section{References}

ALMEIDA, C. C. Processamento auditivo e fonológico em crianças: influência da faixa etária e da alfabetização. 2000. 119 f. Dissertação (Mestrado em Distúrbios da Comunicação) - Escola Paulista de Medicina, Universidade Federal de São Paulo, São Paulo.

AMERICAN NATIONAL STANDARS (ANSI). New York, 1987.

AMERICAN NATIONAL STANDARS (ANSI). New York, 1989.

AMERICAN SPEECH-LANGUAGE-HEARING ASSOCIATION (ASHA). Central auditory processing: current status of research and implications of clinical practice. Rockville, 1995.

BAMIOU, D. E.; MUSIEK, F. E.; LUXON, L. M. Etiology and clinical presentations of auditory processing disorders. Arch Dis. Child., v. 85, n. 5, p. 361-365, 2001.

BOCCA, E.; CALEARO, C..; CASSINARI, V. A new method for testing hearing in temporal lobe tumors. Preliminary report. Acta Oto-Laryngol., v. 44, p. 219-221, 1954. 
CÂMARA, C. C. Testes de escuta dicótica de dissílabos em crianças com e sem evidências de problemas escolares el ou alteração das habilidades auditivas. 1998. $128 \mathrm{f}$. Dissertação (Mestrado em Distúrbios da Comunicação) Escola Paulista de Medicina, Universidade Federal de São Paulo, São Paulo.

CHERMAK, G. D.; MUSIEK, F. E. Managing central auditory processing disorders in children and youth. Am.J. Audiol., v. 1, n. 3, p. 61-66, july. 1992.

CHERMAK, G. D.; MUSIEK, F. E. Auditory training: principles and approaches for remediating and managing auditory processing disorders. Sem. Hear., v. 23, n. 4, p. 297-308, 2002.

COSTA, L. P.; PEREIRA, L. D.; SANTOS, M. F. C. dos. Auditory fusion test in scholars. Pró-Fono Revista de Atualização Científica, Barueri, v. 16, n. 2, p. 187-196, maio-ago. 2004.

FELLIPE, A. C. N. Análise comparativa entre testes de processamento auditivo central e o desempenho em tarefas de leitura e escrita . 2000. 150 f. Dissertação (Mestrado em Distúrbios da Comunicação) - Escola Paulista de Medicina, Universidade Federal de São Paulo, São Paulo.

FELliPE, A. C. N.; COLAFÊMINA, J. F. Avaliação simplificada do processamento auditivo e o desempenho em tarefas de leitura e escrita. Pró-Fono Revista de Atualização Científica, Barueri, v. 14, n. 2, p. 225-234, 2002.

FROTA, S. Processamento auditivo: estudo em crianças com transtornos específicos da leitura e da escrita. 2003. 240 f. Tese (Doutorado em Distúrbios da Comunicação) Escola Paulista de Medicina, Universidade Federal de São Paulo, São Paulo.

GARCIA, V. L. Processamento auditivo em crianças com e sem distúrbio de aprendizagem. 2001. $313 \mathrm{f}$. Tese (Doutorado em Distúrbios da Comunicação) - Escola Paulista de Medicina, Universidade Federal de São Paulo, São Paulo.

HEIERVANG, E.; STEVENSON, J.; HUGDAHL, K. Auditory processing in children with dyslexia. J. Chil. Psyc. Psych., v. 43, n. 7, p. 931-938, 2002.

JERGER, J.; MUSIEK, F. E. Report of the consensus conference on the diagnosis of auditory processing disorders in school-aged children. J. Am. Acad. Audiol., v. 11, n. 9, p. 467-474, 2000.

KING, W. M. Comorbid auditory processing disorder in developmental dyslexia. Ear Hear., v. 24, n. 5, p. 448-456, 2003.

KOLB, B.; WHISHAW, I. Q.Neurociência e comportamento . Barueri: Manole, 2002.
KRAUS, N. Auditory pathway enconding and neural plasticity in children with learning. problems. Audiol. Neurotol., v. 6, n. 4, p. 221-227, 2001.

LEMOS, S. M. A. Análise de sons não verbais sobrepostos por escolares: influência dos distúrbios da comunicação e da audição. 2000. 201 f. Dissertação (Mestrado em Distúrbios da Comunicação) - Escola Paulista de Medicina, Universidade Federal de São Paulo, São Paulo.

MONCRIEFF, D. W.; MUSIEK, F. E. Interaural asymmetries revealed by dichotic listening tests in normal and dyslexic children. J. Am. Acad. Audiol., v. 13, n. 8, p. 428-437, 2002.

MOORE, J. K. Maturation of human auditory cortex: implications for speech perception. Ann. Otol. Rhinol. Laryngol., v. 11, n. 5, p. 7-10, 2002.

MUSIEK, F. E.; GOLLEGLY, K. M. Maturational considerations in the neuroauditory evaluation of children. In: BESS, H. Hearing impairment in children. Maryland: York Press, 1988. cap. 15, p. 231-250.

PEREIRA, L. D.; SCHOCHAT, E. Processamento auditivo central: manual de avaliação. São Paulo: Lovise, 1997. Parte 2, Parte 1, cap. 5, p. 49-60.

PHILLIPS, D. P. Central auditory system and central auditory processing disorders. Sem. Hear., v. 23 , n. 4 , p. 251-261, 2002.

PONTON, C. W.; EGGERMONT, J. J.; KWONG, B.; DON, M. Maturation of human central auditory system activity: evidence from multi-channel evoked potentials. Clin. Neurophysiol., v. 111, n. 2, p. 220-236, 2000.

PURDY, S. C.; KELLY, A. S.; DARVIES, M. G. Auditory brainstein response, middle latency response, and late cortical evoked potentials in children with learning disabilities. $J$. Am. Acad. Áudio., v. 13, n. 7, p. 367-382, 2002.

SCHOCHAT, E. Desenvolvimento e maturação do sistema nervoso auditivo central em indivíduos de 7 a 16 anos de idade. 2001. 155 f. Tese (Livre-Docência) - Departamento de Fisioterapia, Fonoaudiologia e Terapia Ocupacional da Faculdade de Medicina da Universidade de São Paulo, São Paulo.

SCHOCHAT, E.; RABELO, C. M.; SANFINS, M. D. Processamento auditivo central: testes tonais de padrão de frequiência e de duração em indivíduos normais de 7 a 16 anos de idade. Pró-Fono Revista de Atualização Científica, Barueri, v. 12, n. 2, p. 1-7, 2000.

WERTZ, D.; Hal III, J. W.; Davis II, W. Auditory processing disorders: management approaches past to present. Sem. Hear., v. 23, n. 4, p. 277-285, 2002. 